Georgia State University

ScholarWorks @ Georgia State University

Middle and Secondary Education Faculty

Publications

Department of Middle and Secondary Education

2016

\title{
Disrupting ELL Teacher Candidates' Identities: Indigenizing Teacher Education in One Study Abroad Program
}

G. Sue Kasun

Georgia State University

Cinthya M. Saavedra

Utah State University

Follow this and additional works at: https://scholarworks.gsu.edu/mse_facpub

Part of the Curriculum and Instruction Commons, and the Junior High, Intermediate, Middle School Education and Teaching Commons

\section{Recommended Citation}

Kasun, G. Sue and Saavedra, Cinthya M., "Disrupting ELL Teacher Candidates' Identities: Indigenizing Teacher Education in One Study Abroad Program" (2016). Middle and Secondary Education Faculty Publications. 49.

https://scholarworks.gsu.edu/mse_facpub/49

This Article is brought to you for free and open access by the Department of Middle and Secondary Education at ScholarWorks @ Georgia State University. It has been accepted for inclusion in Middle and Secondary Education Faculty Publications by an authorized administrator of ScholarWorks @ Georgia State University. For more information, please contact scholarworks@gsu.edu. 


\section{INDIGENIZING TEACHER EDUCATION}

Educating teachers in our current global context poses challenges for teacher preparation programs (Darling Hammond, 2007); the context is differently complex for preparing teachers of English language learners (ELLs) due to the intersections of empire and English and how they bear out on the TESOL field (Motha, 2014). The predominantly white women U.S.-based preservice teachers (Picower, 2009) and their teacher educators generally possess a Western epistemology that does not naturally articulate with their English language learners' (ELL) linguistic and cultural differences (Author 1, 2014). In this study we explore the educational experiences that positively impacted teacher candidates' identities through a carefully crafted indigenizing study abroad program. In this article, we discuss the answer to our research question: Were the identities of apprentice teachers impacted by the study abroad program, and if so, how?

The four-week study abroad program explicitly centered indigenous ways of knowingways of knowing that highlight the interconnectedness of all things through the wisdom of indigenous sources - in both formal readings and in experiential learning. We chose indigenous ways of knowing as contextually appropriate for the learning context and for the many future ELLs with whom the teacher candidates would work, as Mexicans have been theorized as having maintained much indigeneity despite colonization (Bonfil Batalla, 2007); also, indigenizing the curriculum has been advocated as one of several effective approaches toward creating a more socially just pedagogy and world (Arrows, 2013; Pete, Schneider \& O’Reilly, 2013). As a result of the program, which occurred in summer 2014, each of eight teacher candidates described and demonstrated identity changes regarding their future work with ELLs. This critical approach to teacher preparation created "cracks between worlds" (Anzaldúa, 2002) that allowed teachers candidates to rethink their identities as ELL teachers in local and global contexts. 


\section{INDIGENIZING TEACHER EDUCATION}

In this article, we describe and theorize the challenges and promises of exposing teacher candidates' identities to teaching experiences that deliberately resist epistemologies associated with dominant forms of Western knowledge in this study abroad program. We discuss alternatives to preparing teacher candidates interested in working with culturally and linguistically minoritized communities. We embraced a critical approach that "encouraged desocialization via ideological disembedding," (Kincheloe, 2003, p. 52) thus opening a space for teacher candidates to decenter themselves in order to reflect upon the possibilities of engaging other worlds. We start by situating the literature of U.S. teachers of English learners that point to their whiteness. We do so because our work as teacher educators is preparing mostly white pre/in-service teachers. The literature we explore subsequently highlights a focus on race. We see our roles as teacher educators as creating spaces where teacher candidates can unpack their Western identities and their ways of knowing. By Western identities, we refer to identities rooted in colonialists' logic (Calderon, 2014) and understanding of the world that go unchallenged in day-to-day activities that all of us must unpack, regardless of culture or racial ethnic markers within the U.S. We also understand this term is problematic and deserves more nuance (see Bhattacharya, 2011; Hall, 2002). Because of the colonialist nature of schooling (Calderon, 2014 for this particular study abroad program we found it necessary to use indigenous knowledge frameworks, theoretically and methodologically, as a way to facilitate the space where participants could challenge and problematize their Western colonialist identities conceptions of schooling. We then present the findings, followed by implications for teacher education.

\section{U.S. teachers of English language learners}




\section{INDIGENIZING TEACHER EDUCATION}

In the field of TESOL, there has been emerging and important scholarship regarding race and its impact on educators and students (Curtis, 2006; Grant \& Wong, 2008; Kubota \& Lin, 2006). In this literature, there is an identified gap in the research on exploring whiteness and

ELL educators (Motha, 2014). White teachers and pre-service teachers are situated at one of the last frontiers to which a critical racial analysis has begun to arrive. It should be noted that this analysis seems to be following research in more general teacher education literature, where theorists have been examining white pre-service and in-service teachers' work, especially with minoritized students (see, for instance, Sleeter, 2001; Valenzuela, 1999; Foley, 1994; Howard, 1999). In the studies which have been conducted with white pre-service and in-service ELL teachers, researchers have found white teachers successfully unsettled in their beliefs by doing the hard work of self-reflection regarding race and privilege, though at times there are deep resistances to such unsettling (Motha, 2014; Ligett, 2009). We recognize that not all white preservice teachers are completely unaware of their positionality, as they may have previously engaged in self-reflective activities through life and educational experiences.

Motha (2014) spent a year working closely with and examining the first year efforts of four in-service ELL teachers, one Korean heritage and three white. Using lenses of postcolonialism with a critique of empire's impact on education — and especially racially/linguistically minoritized youth—she shows the teachers' struggles to work toward empowering their students despite structural constraints they and their students faced. She explains the terrain of U.S. schools is weighted against ELLs. As a way to correct this structural inequity, Motha argues:

Teacher education, both in TESOL and within other disciplines, should consistently and forcefully focus on teacher agency, applying a specific and deliberate emphasis on the 


\section{INDIGENIZING TEACHER EDUCATION}

role that teachers play in shaping the power relations, access to resources, and positionality of their linguistic-minority students. It is not enough for teachers to be familiar with second language acquisition theory and be able to name and identify a variety of ESL methods.

Motha found the teachers wanted to and attempted to work toward advocacy for minoritized students, but the system of empire itself often eclipsed their efforts from the start. Hence, she recognized the needs for teachers to have greater agency in their work in order to more effectively both teach and do advocacy for English learners. In her recommendations, Motha drew upon Kumaravadivelu (2003), who “advocates for 'postmethod pedagogy,' which includes a sensitivity to location- and context-specific particularities and the transformative intellectual agility to craft fitting pedagogies in response to a given situation” (p. 140-141, Motha, 2014). Similarly, Saavedra $(2004 ; 2011)$ reminds us that there is more to educating ELLs than a focus on language acquisition and that often because of terms such ELL, ESL, LEP, we only see ELLs as language without bodies. This conclusion provides a practical way in which educators may go forth to do work with a focus on equity as well as educating English language learners holistically.

\section{Theoretical framework}

The study abroad program and research were conceptualized through an indigenous knowledge framework (Arrows, 2013; Cajete, 2000; Kincheloe \& Steinberg, 2008; Ruiz, 1997; Peat, 2002). It also centered critical self-reflection on what it means to be an ELL teacher. Since these identity reflections were part of the program, it added to the need to use identity theory and in particular figured worlds (Holland, Lachicotte Jr., Skinner, \& Cain, 2001). Below we elaborate on both of these frameworks. 


\section{INDIGENIZING TEACHER EDUCATION}

\section{Indigenous knowledge}

Though indigenous knowledges are diverse and multiple, we are grounding our notion of indigenous knowledge from scholars who have document indigenous knowledges for wider audiences. Where possible we highlight their specific tribe or locality. North American Indigenous scholar Cajete (2000) explains that Native science or indigenous knowledge is a way of knowing that:

extends and includes spirituality, community, creativity... questions such as the nature of language, thought and perception; the movement of time and space; the nature of human knowing and feelings; the nature of human relationship to the cosmos; and all questions related to reality drawn from the experience of thousands of human generations (p. 3).

Our research embraces this depth of interconnectedness in how students engaged understandings of so many interwoven aspects of a complex study abroad experience. At the same time, this framework also underpins the knowing that Author 1 intended to help students explore by participating in the program.

Teacher candidates convivían, co-participated with a depth of connection beyond merely being physically present, (Trinidad Galván, 2011) in Mexico with indigenous centered schools’ students and directors as a way to de-center Western education and to grasp different visions of education. Therefore, it was necessary for the students to read and engage with different ways of knowing (Kasun \& Saavedra, 2014; Meyer, 2008; Peat, 2002). Students read The Four Agreements by Mexican Indigenous author Don Miguel Ruiz (1997). This reading was crucial, as one of the indigenous based schools they participated in centered the school's philosophy on the Toltecs who were "scientists and artists who formed a society to explore and conserve the spiritual knowledge and practices of the ancient ones... Toltec knowledge arises from the 


\section{INDIGENIZING TEACHER EDUCATION}

essential unity of truth as all the sacred esoteric traditions around the world" (p. xiii-xiv).

Furthermore, as a way to question our socially constructed lives, Ruiz describes our unaware lives as a dream. And, once we acknowledge that dream we can contemplate our lives through more conscious living. To accomplish this, Ruiz, offers us a way to examine our lives through the four agreements: be impeccable with your word, don't take anything personally, don't make assumptions, and do your best (Ruiz, 1997). These may sound simple, but, in practice, they are daunting, complicated, and at the same time, liberating (Ruiz, 1997).

As scholars in a Western dominant society, we concur with Kincheloe and Steinberg (2008) that it is imperative that we embrace understanding indigenous knowledge as a way to extend students' "cognitive abilities, as they create situations where students come to view the world and disciplinary knowledge from as many frames of reference possible" (p. 139). It is through this reframing that students can escape their otherwise Western-centric lives. Four Arrows (2013) explains, “...many scholars and philosophers have referred to the potential of using indigenous wisdom to transform learning” (p. 4). Similarly, Battiste (2005, as quoted in Arrows 2013, p. 4) argues "Indigenous knowledge fills the ethical and knowledge gaps in Eurocentric education, research and education scholarship.” Arrows reminds us that “...Indigenous teaching and learning paths are ultimately about cultivating cognition and consciousness via spiritual awareness and reflection on lived experiences" (p. 65). We come full circle to the inclusion of the Four Agreements as part of the curriculum for the students to both see the application of its Toltec wisdom and to have the opportunity to apply it to their own experiences.

For analysis of an indigenously-oriented study abroad, it followed to use a similar theoretical framing, especially to help decipher blind spots in the Eurocentric training we have 


\section{INDIGENIZING TEACHER EDUCATION}

received in the academy. Author 1 used the same indigenous knowledge readings to guide her research lens in order to unearth the ways students were rethinking their identities otherwise missed through other lenses.

\section{Identity theory through figured worlds}

Because the study abroad program was designed to also address self-reflection on Western education in terms of what it means to be a teacher of ELL students, we were then guided by a sociocultural understanding of identity construction and agency through figured worlds to make sense of students' shifting senses of identity. Individuals are both categorized and categorize themselves into identification groups, and not into single and static identity categories (Holland, Lachicotte Jr., Skinner, \& Cain, 2001; Holland Herring \& Lave, 2001). Identities are contingent upon a person's positioning in a moment in time and in selfwhat is referred to as history-in-person (Holland Herring \& Lave, 2001). History-in-person is the individual's series of life experiences and senses of self-authoring, such as belonging to Alcoholics Anonymous and crafting one's story as a member, or as an out-member, or among the tensions of these narratives alongside other groups or figured worlds a person belongs to (Holland, et al., 2001). Individuals can position themselves in a shifting multiplicity of identities, ones that include heteroglossia of meaning in their internal dialogue and heteroglossia in their external dialogue (Holquist, 1981). Their internal and external dialogues can have multiple meanings, which may at times appear to be in conflict with each other.

Holland et al (2001) explain there is not unlimited difference, which makes each individual unique in his or her own unique world. That is, each individual could not simply claim an identity and thus comfortably live and perform it unchallenged. They theorize, instead, that individuals are part of social worlds in which multiple members share similar understandings of 


\section{INDIGENIZING TEACHER EDUCATION}

belonging in communities of practice, referred to as "figured worlds," ranging, for example, from memberships in groups such as the Black Lives Matter movement to the figured world of romance, wherein people engage the practices of courtship and dating, a set of practices not always historically performed in many cultures (Holland, et al., 2001). They also show how people are positioned by their circumstances - that is to say they do not have unlimited agency to experiment in whatever figured world she or he may wish (Holland et al., 2001). Ultimately, people may and do act with agency as it hinges upon their history-in-person and the figured worlds with which they belong, both insofar as they are situated without will into the figured worlds and within which they choose to affiliate with the figured worlds (as they always operate in tension). Because the way a person identifies and is identified are intricately linked with what and how people know, it was important to have a sense of the identities of the research participants. For this research, this understanding helped to theorize the multiple and simultaneous identities of research participants as well as better contextualize both our understanding and the results of the data.

\section{Methodology}

The research of this critical program was conducted as critical ethnography by the first author wherein she used critical lenses to both craft the program, with the help of author 2 , and research it with a goal of helping create positive social transformation (Foley, 2002; Madison, 2011). Specifically, author 1 used a participatory action research (PAR) approach to critical ethnography (Foley \& Valenzuela, 2005) in terms of co-participating with the teacher candidates toward goals of all the participants' increased senses of interconnectedness and toward helping prepare them to be teachers with the agency. This was the kind of agency for which Motha (2013) argued to be able to work against the ways schools often further colonize ELLs through 


\section{INDIGENIZING TEACHER EDUCATION}

language instruction. The intention of this methodology, alongside the program, was for it to be decolonizing (Smith, 2016) for the participants as well as for the author. Traditional power dynamics were disrupted regularly with the students and inverted toward having the students make decisions about the program and to speak freely and purposefully. The first author attempted to demonstrate a profound sense of authentic care (Valenzuela, 1999) toward the goal of achieving these decolonizing processes and ends, which, to be clear, we do not believe can be fully accomplished in just four weeks. Such care was reciprocated in authentic relationships even among the family members of Author 1 who participated in the study abroad program as well (see, for instance, Author 1, 2015). For the first author, creating a sense of authentic community among the participants through authentic care was paramount. She followed through with this goal in providing her home as a space for focus groups and several other get-togethers for all participants and maintains mentoring relationships with several of the participants at the time of publication of this article.

Part of the intention of critical ethnography is to interrogate the positionality of the researcher (Madison, 2011). In the case of the first author, she recognizes her first read on the outside is that of a white woman. This opens countless doors of unearned privilege the world over. At the same time, she recognizes the vast array of life experiences that she carries with her to comprise many of her sensibilities, including her classed upbringing in West Virginia (Author, 2013) and her acquired bilingualism through her own semesters studying abroad on scholarship in Mexico with a social justice program. Her own process toward decolonization has been a long and incomplete journey, one about which she was cautious as she attempted to work toward decolonization among the teacher candidates. 


\section{INDIGENIZING TEACHER EDUCATION}

The study abroad program was explicitly designed for teacher candidates seeking an ESOL endorsement with the intention of decentering participants toward the ends of learning decolonizing pedagogies. Author 1 established the program with a social justice-oriented, Freirean language school, "Estrella Language Institute," (a pseudonym, as are all names in this article) in a city in Mexico. This language institute was unique in its emphasis on having its students name the world as the realities presented themselves in the daily lives of ordinary Mexicans, as opposed to the more tourist-oriented attractions of Mexico. Students studied Spanish daily for about four hours, and the school built many social justice as well as indigenous issues into the curriculum, which included visits to indigenous schools, community centers, museums, and hosting guest speakers and documentary screenings. To illustrate, teacher candidates learned both struggles of immigration as well as Mayan cosmovision from a Guatemalan shaman. Another example was how the teacher candidates toured the local municipal market - with the curricular frame of having to figure out how to feed a family on one Mexican minimum wage. Finally, Estrella Language Institute arranged for host family stays among lower-income families in which the families had been trained to engage discussion of issues related to social justice as well as to be very supportive and social with students during the stays. The Estrella director and faculty met daily with Author 1 in Mexico with questions and ideas for building a constantly responsive set of practices and experiences to maximize student growth and learning. The school personnel emphasized that they attempt to have students and visitors feel that they are "among family;" the relationship was generative and respectful.

Author 1 coordinated all curricular activities with Estrella in concert with her university courses, which she designed in consultation with Author 2, who had also studied Spanish at Estrella previously and spent time observing the indigenous based school. Author 1 taught three 


\section{INDIGENIZING TEACHER EDUCATION}

courses: linguistic and cultural diversity, second language acquisition theory, and strategies of teaching ESOL across the content areas. Students completed most of the readings prior to leaving, including several days of instruction in the U.S. related to the readings. The readings emphasized indigenous knowledge, critical pedagogy, critical perspectives related to Mexican history and immigration, especially in complicating how immigration can largely be reframed as a process of transnational practices (Kasun \& Saavedra, 2014). Reframing the discourse of immigrant as transnational helps educators see that those who migrate to another country have experiences and knowledges that could enhance learning for all in the classroom. Readings also included instructional articles related to "how to teach" these issues - and sociocultural approaches to learning language. During their time in Mexico, the students met twice weekly and submitted several reflective assignments, including self-assessments related to the curriculum and their experiences while in Mexico. Upon return, the students completed final projects synthesizing their learning in the form of digital stories, reflective essays, and lesson plans.

\section{Participants}

The participants included eight teacher candidates. Pseudonyms are used for all participants. Teacher candidates ranged between age 19 to 41 , the majority of them single and in their 20 s. All were women pursuing degrees in elementary education, and all but one were white as well as Latter-day Saints (LDS). One woman, Marci, self-identified as half Native American, half white, and she was not LDS. The students hailed from middle class to lower socio-economic status backgrounds, and each had completed at least one semester of coursework in the university's teacher education program. Teacher candidates had applied through the standard university online application, which included a short essay regarding their intentions for applying and a reference from a faculty member. 
INDIGENIZING TEACHER EDUCATION

Table 1. Research participants

\begin{tabular}{|l|l|}
\hline \multicolumn{1}{|c|}{ Participant Name } & \\
\hline Loren, married Age \\
\hline Melissa, single & 27 \\
\hline Marci, married mother of Native American heritage & 19 \\
\hline Lindsey, single & 41 \\
\hline Amy, single & 22 \\
\hline Mandy, single & 22 \\
\hline Ellie, single & 20 \\
\hline Janet, single & 22 \\
\hline
\end{tabular}

\section{Data}

Author 1 analyzed data from all eight teacher candidates. The data included written selfreflections, other class assignments (Bowen, 2009), class discussion notes, and reflective ethnographic journals (Boylorn \& Orbe, 2013) of Author 1. Focus groups were conducted every three months upon return at Author 1's home, and they were voluntary and open to all participants; each session lasted between 70 and 90 minutes. A minimum of four students participated in each focus group session. The focus group sessions were conducted about the following topics: changes in sense of self upon return, changes in ideas regarding education, and senses of relationships to self and others. Following is a list of all data sources:

Table 2. Data sources

\begin{tabular}{|l|l|l|}
\hline Data item & Description & Length/duration \\
\hline $\begin{array}{l}\text { Teacher candidates' self } \\
\text { reflections written during } \\
\text { program }\end{array}$ & $\begin{array}{l}\text { Eight total assignments of all } \\
\text { eight participants }\end{array}$ & Two pages \\
\hline $\begin{array}{l}\text { Final projects, completed } \\
\text { upon return }\end{array}$ & $\begin{array}{l}\text { Five total assignments } \\
\text { completed upon return }\end{array}$ & Range: six to eight pages \\
\hline Class discussion notes & $\begin{array}{l}\text { Running record of jottings } \\
\text { filled out later by Author 1 }\end{array}$ & 30 pages \\
\hline $\begin{array}{l}\text { Ethnographic field notes of } \\
\text { Author 1 }\end{array}$ & Written daily & $\begin{array}{l}\text { Approximately 3-8 pages per } \\
\text { day }\end{array}$ \\
\hline Focus group sessions & $\begin{array}{l}\text { With at least four } \\
\text { participants, conducted over a } \\
\text { meal at Author 1's home }\end{array}$ & $\begin{array}{l}\text { Three 70-90 minute sessions; } \\
\text { each transcribed }\end{array}$ \\
\hline
\end{tabular}

\section{Analysis}




\section{INDIGENIZING TEACHER EDUCATION}

Author 1 analyzed focus group sessions with the available participants. Author 1 did open and focused coding of data to generate themes of analysis (Saldaña, 2009); she made an Excel spreadsheet of codes, categories, and themes as they emerged for easier use in interpreting data. In the open coding, Author 1 analyzed all data line-by-line to search for salient themes related to identity. The open coding of initial data included codes such as being hopeful, formerly being unaware (of the sociopolitical circumstances driving transnational/immigrant practices), not assuming, and accepting difference. Author 1 continued to work through the data with open coding toward keeping a sense of openness for additional emergent themes and to complicate initial themes as necessary. In additional cycles, she re-analyzed the data with focused coding, relying on the framework of indigenous/decolonizing knowledge and figured worlds (Emerson, et al., 1995). This led to analytical coding of themes that cohered from various sets of data into the areas presented below, including being socially aware, being empaths, and being creators of loving classroom spaces. Author 1 conducted member checks (Lincoln \& Guba, 1985) with multiple participants from the study abroad who roundly concurred the findings accurately described their identity shifts.

\section{Findings: Shifts and cracks in ELL teacher candidates' identities}

Teacher candidates experienced a host of shifts in terms of their understandings of identity during the four-week program and even upon return, as evidenced in focus groups throughout the academic year. There are three major areas with deep connections to indigenous/decolonizing identities that emerged in the research, alongside tensions to figured worlds the students engaged. The areas include: being socially aware, "beyond the dream" as presented in The Four Agreements (1997); being empaths and those who engaged in serious selfwork of deep personal introspection; and being creators of a loving learning space - as opposed 


\section{INDIGENIZING TEACHER EDUCATION}

to classroom managers. We explore each of these areas subsequently, illustrating each with examples from students' reflections and some of their experiences during the program. We organize the areas loosely along chronological shifts in identity formations through each of the three domains. To be clear, these identity formations are not entirely linear, though students tended to engage these identity categories along these three stages. The categories, however, then often held together and in tension with each other.

\section{Being socially aware-Beyond "the dream"}

In the beginning of Ruiz's (1997) Four Agreements, he explains that what we as humans perceive as reality is actually a socially conditioned set of understandings. Ruiz explains that a person must learn to comprehend the uninterrogated understandings we carry in the world to be able to begin to make a conscious choice regarding our beliefs and how we want to be in the world. He explains the ways of the world include understandings that are fraught with judgment and lead to self-blame, instead of action which the individual chooses and owns with the confidence that they have "done their best," one of the Four Agreements. It was only upon experiencing Mexico that teacher candidates began to do the decolonizing work of recognizing their dream in the discussions and course work.

Teacher candidates engaged the understandings of reality from a new set of lenses, lenses they recognized as having clarity from having left behind the "dream" of the U.S. Very early on, the students said the material comforts they left behind in the U.S. were not "important at all" as they lived with less with their lower income homestays (class discussion, May 27, 2014). Specifically, during class discussion, students recognized their Mexican families "living more simple lives," in material realities such as not stockpiling groceries, disconnecting appliances when not in use, and using only the minimum amount of paper products as necessary. This stood 


\section{INDIGENIZING TEACHER EDUCATION}

in contrast to their U.S.-based lives that were oriented to more consumerist, and thus further colonizing, approaches to living. This was one of the first times in their lives they recognized that consuming more things was not always better.

Students also noticed the fears they had been told to have by friends, and especially the media, were largely unwarranted. They answered written assignment questions regarding their changing understanding of the "other" (Brown, 2005) as well as their understandings of indigenous ways of knowing. "I used to think Mexico was full of criminals and gangs based on what I saw in the media, now I know nothing could be further from the truth," Melissa shared in one of her written reflections. Teacher candidates began to experience a sort of cognitive dissonance that allowed them to view Mexico and Mexicans from new frames of reference (Arrows, 2013; Kincheloe \& Steinberg, 2008) and to reexamine their U.S. knowledge base and beliefs.

Similarly, students explored uneven power relationships and especially trade agreements, particularly NAFTA, and their impacts on migration flows north from Mexico. Mandy explained in a written reflection:

Since being in Mexico, I've learned so much about NAFTA and the negative effects it has had on the Mexican economy and immigration into the United States. When I was living in [home state], I heard a lot about 'the Mexicans coming to the US and taking our jobs.' I've learned how untrue that is. When NAFTA came into play, one of the most detrimental effects was on Mexico's farming industry.

Upon return to the U.S., students explored their new positioning to recognize and speak out against oppression. Ellie explained in our April focus group meeting: 


\section{INDIGENIZING TEACHER EDUCATION}

Just thinking like since I've been back listening to people say, "That's so gay," or "That's retarded," that like really offends me now when people say that...And I'm like, "You, like you, you are saying things in a negative way about people who aren't here to defend themselves..." Maybe that's like a small thing. But that's like something that I've really noticed, something that I've changed. Helping defend people that aren't like there in the moment.

At the same time, several students referred to the sense of struggle of conveying their social analysis and equated it to the dream described in the Four Agreements (1997). In this sense, they engaged upon the co-constructed figured world of those who understood the "dream" in their struggles to convey the social analyses far more rooted in a reality to which they had born witness. Amy explained in a September 2014 focus group meeting:

I felt kind of like in the book the Four Agreements where he has the dream and he wakes up and tries to tell people and no one sees it or understands and I felt like similar to that coming home. And I felt $[$ like]... how do I be a normal contributor to this universe here, but also maintain my new view of life.

Consequently, the tensions of the world of being in Mexico where a figured world of social analysts who were so socially aware lent itself to discussions regarding the new sense of realities students developed. This contrasted with their return to the U.S., where they appealed to their sense of understanding reality in ways that worked against the "dream" of those they knew in their ordinary communities. Indeed, students expressed tremendous relief to be able to return to the group for focus group sessions to re-engage the same community of practice.

Another figured world the students engaged where the old dream was pervasive was that of being in schools. Most students had begun their student teaching, and several spoke about the 


\section{INDIGENIZING TEACHER EDUCATION}

worries they had about speaking out when they heard racist comments. As good as they had become at recognizing racism and structural oppressions, they found themselves also enmeshed in the figured worlds of schools, as exemplified by Lindsey in the April focus group meeting:

I think what I've heard most with that sort of thing is like stereotypical things that people say. They'll be like, "Oh they're from Mexico so" whatever they say about Mexicans, you know? And teachers talk like that in the workroom and like in the...like at lunch and stuff about their students... I kind of think of it as a...like an ignorance. And so it's still kind of difficult for me when I have people who are older than me or have more education or like these cooperating teachers that I'm supposed to be learning from, it's still hard for me if I hear stuff like that to kind of say anything about it though.

All five of the students present at that focus group meeting admitted to feeling discomfort about engaging the figured world of school in a way that squared well with their roles as social analysts. As such, at times, they chose to not speak up, a choice which was likely strategic in protecting their future employment. At the same time, some students described attempting to gently help others develop the new kind of "dream" by exploring what they had learned in Mexico through stories of people's lives and experiences. The students recognized the story of individuals they engaged in Mexico was one of the best ways to create a sense of interconnectedness (Cajete, 2000) with their colleagues in schools. This attempt to create interconnectedness, based in a social analysis which works against the old dream, demonstrates a part of a partial process of decolonization in the students' identities, one that operates in contrast to a Western approach of simply accepting schooling and discourses about immigrant students as given.

\section{Being empaths: Self-work}




\section{INDIGENIZING TEACHER EDUCATION}

Marx and Pray (2011) provide a nuanced definition of empathy beyond the more common-sensical notion of "walking in another's shoes;" their definition invokes the recognition of unequal power relations regarding race in society. Specifically, they define empathy as requiring "first-hand experience with the struggles and experiences of another" in a way that engages understandings and shifts of power relations toward personal and social transformation (p. 511). Students frequently reflected on their depth of their increasingly decolonized understanding regarding the challenges to one's language learning process and one's very identity in learning a language. Students expressed how they thought they knew what it was like to learn a language until they had the full immersion experience of studying abroad in Spanish daily. During the third week, Mandy wrote in her self-reflection:

Now I will be more empathic towards transnational learners. Before going to Mexico, I had the idea that if you were immersed in a language, you would be able to learn and understand more quickly. I had the idea that if you were to just sit there, learning was taking place. Little learning takes place when there are no adaptations. Now that my thoughts are starting to be decolonized, I know changes I can make within the classroom to better my teaching to help my students.

Mandy recognized the ways her thoughts were being decolonized and action strategies pursuant to her future role as classroom teacher, strategies we describe in the final section. Similarly, Melissa situated her identity in a fascinating community of practice, that of Spanish learners. During the April 2015 focus group meeting, she shared:

I also feel like I have gained the identity of a Spanish language learner. I remember one day we were in the museum...And we were speaking Spanish only. And it was so hard! I just wanted to lay on the ground in the museum and just sleep or cry or both because it 


\section{INDIGENIZING TEACHER EDUCATION}

was so hard. I just had to stare at Ernesto [instructor] to just try and understand what he was saying.... So I just think of those kids who can't speak English, how do they sit through a whole day of school without just laying on the ground and crying? Because I'm an adult...

There was recognition of the other in the self, indeed, based on experience and openness to a recognition of our interconnectedness (Cajete, 2000). Melissa could have focused solely on her own frustration, but she made the direct connection to ELLs as part of her knowing and as a deep demonstration of her empathy. This empathy was described at length throughout the program by teacher candidates and remained durable even upon return, and we attribute it in large part to the robustness of how much the teacher candidates worked toward understanding the other and seeing themselves in the Mexicans with whom they were able to convivir.

To illustrate, we refer to one of the indigenously oriented schools with which we partnered, named Escuela Raices. This school provided a free breakfast for all who attended and offered workshops, where the Four Agreements were lived every day. The youth who participated were among the materially poorest. After a third full day of convivencia (meaningfully being with) with the youth and instructors at the school, one of the directors spent time evaluating the day's work with us. She emphasized how none of the youth were obligated to attend, that they genuinely chose whether or not they participated in efforts to embrace the agreement to "do your best." Lindsey, the next day, during our third week of classes, explained:

I thought a lot about the open environment of Escuela Raices, where students were allowed to choose whether or not they attended the school. The most important thing for me, though, is to work on myself. That means me living the Four Agreements, as hard as they are. 


\section{INDIGENIZING TEACHER EDUCATION}

In a similar effort to do self-work, several students said they became more spiritual as a result of the program. Students described having their sense of identity either "broken down" during the program or "built upon" due to the intensity of the curriculum and experiences. Two of the students described doing ancestry research specifically because they had been on the program. Melissa explained she learned more about her roots because of the indigenous orientation of the program:

Now I'm just so interested to know where are they [her family] from. What were they like, my ancestors? Because I think they showed how important it was to them, like the indigenous people and keeping that alive in Mexico. Even when we learned about the medicinal plants, I loved that day.

Melissa referred to the figured worlds of ancestors and how important they were to the indigenously oriented ways of knowing we bore witness to in Mexico, highlighting specifically our visit to an ethnobotanic garden where the guide spoke at length about her pride in her indigenous heritage and her ancestors' understanding of the uses of medicinal and ritual plants. Cajete's (2000) definition of indigenous knowing can be captured in Melissa's search for roots, spirituality and community.

\section{Creators of loving learning spaces: Not classroom managers}

The students embraced indigenous approaches to learning and knowing toward constructing their identities as creators of loving learning spaces. This worked in contrast with their figured worlds surrounding their roles as "classroom managers." The teacher candidates developed new visions for their roles as crafters of these education spaces. We explore these two in tension with each other, as they were nearly always described together by teacher candidates 


\section{INDIGENIZING TEACHER EDUCATION}

both during the program in Mexico and upon return, hinting at the collision of decolonizing and colonizing figured worlds.

During a class discussion in the fourth week of the program, Amy described a conversation she had with Mandy. They discussed how they think they have a plan for what they teach, but that the plan is actually a "tentative thing." She related this to the flexible instruction she witnessed with so few physical resources, but with a strong underpinning of purpose with meaning at Escuela Raices. Amy then went on to explore how her figured world of being an excellent "classroom manager" had been challenged:

Gosh dangit! When it came to working with kids in schools, I had a plan and confidence. I've had a lot of reinforcement for that. I've been told I am a pro at making kids behave [in a student teaching placement]. But what I know now about the Four Agreements and how I've seen them in action... it's good information. I like it. I'm not sure how it will come out, and that's ok.

Amy concluded with a comment that conflicted with her initial thought, precisely the way Holland et al (2001) describe how we figure our worlds at times in conflict and through tensions simultaneously. We note this tension as one toward colonizing children in schools with teachers as classroom managers, managing the children, and one that is decolonizing where children are loved and treated as interconnected members and provided freedom to learn.

The identity shift away from being classroom managers to being creators of loving spaces remained durable through the end of the academic year. Here is one typifying case from Ellie, as shared during our focus group meeting in April:

I think my identity as a teacher has [changed]. I feel like education is a lot, like my idea of education is a lot different. I feel like it's more about fostering learning not like 


\section{INDIGENIZING TEACHER EDUCATION}

teaching [students/learners] everything. It's about helping them get this experience where they learn to love to learn. And yes you teach them the curriculum they need to learn and yes you do whatever you have to do as a teacher, especially public education, to do the standardized testing stuff... But being able to create an environment that they can learn in and learn to love it, I think, was something that I always was like, "Oh yeah it's important to learn, the kids need to learn to love learning." But I really feel like that's how I identify as a teacher. That's my goal as a teacher... is to create that, not just to like teach them stuff.

When asked, Ellie and the other teacher candidates agreed this conception of creating the classroom as a loving space was born from their experiences both with Escuela Raices and Estrella language institute where they studied. At the same time, we recognize several conversations students had while in Mexico and upon return about the job interview for teaching positions. In this sense, they participated in the figured world of teaching as job applicants. They struggled between the "right" answer for the job interview about "classroom management," which they described as having a clear plan of behavioral strategies and the one they had embraced in terms of allowing people to be who they are, especially when framed in the Four Agreements. We remain cautiously hopeful their newly figured worlds of identification as creators of these loving space classrooms remain durable, even perhaps alongside the figured worlds of teachers with behavior plans in place.

\section{Implications and conclusions}

Carefully reflecting upon developing the study abroad program, the experiences in Mexico, and gatherings back in the U.S, this study has several implications for ELL teacher education and for creating potentially decolonizing spaces where teacher candidates can rethink 


\section{INDIGENIZING TEACHER EDUCATION}

and perhaps even transform their identities. We in no way set out for the students to "go native" through this indigenizing experience but instead to set aside the paradigm from which most students in the U.S. have been instructed, a Eurocentric one where the scientific method and empiricism dominate (Kincheloe, 2008). This Eurocentric focus precludes recognition of knowing through anything but the five senses, and the introduction of indigenous knowledge allows space for engaging reality differently, through a recognition of colonial histories not written by the victors to engaging the spiritual and ancestral (Cajete, 2000). By decentering their knowledge paradigms, teacher candidates were able to begin to understand the ways of knowing of others. As part of this decolonizing process, they naturally began adapting some of these ways of knowing, as evidenced in the teacher candidates' work and upon return, months later. They began using language surrounding Ruiz's recognition of the false "dream" of reality and discarding their old senses of knowing regarding the "other" (Brown, 2005). We do not assert the teacher candidates were indigenized but that their ways of knowing became porous toward adapting "cracks between worlds," (Anzaldúa, 2002) to include adaptations of ways of knowing. These "cracks between worlds" provide a productive space to engage shifts and chasms between figured worlds (Holland et al., 2001), including figured worlds newly created in the program.

We urge teacher educators to include spaces for intentional decolonizing, decentering, and desocializing (Kincheloe, 2003) for their teacher candidates. These spaces should be designed to provide teacher candidates with opportunities to recognize and question the "dream," toward an awakening where they engage reality through agreements of being, which are deeply respectful toward the teacher candidates themselves and all around them (Ruiz, 1997). The follow-up provided after the program provided one way to ease tensions teacher candidates experienced between their figured worlds at home and abroad. We recognize a need for 


\section{INDIGENIZING TEACHER EDUCATION}

additional, on-going spaces in teacher education that can allow new knowledges to surface, so that they can be contemplated and sustained.

The critical education experiences, alongside indigenous knowledge and wisdom exposure, were key in helping teacher candidates rethink their identities. This study abroad program centered the very context students engaged, in this case Mexico, and more specifically Mesoamerican indigenous knowledge and ways of knowing. In other words, the U.S. based university did not export critical education to Mexico allowing ourselves the opportunity to "hear" marginalized subaltern knowing as the guiding voice driving the curriculum. We also note teacher candidates did not take up the explicit language of anti-racism, and recognition of white privilege, which are often goals of our own U.S.-based work with teacher candidates, as much as they did of decolonization and a depth of empathy toward ELLs. This suggests, to us, the need to allow room for multiple effective approaches toward social justice in ELL teacher education and teachers' identity development (Saavedra, Chakravarti \& Lower, 2009) and also to allow for the complications of often "over-simplified" identity of whites, mindful, of course, of the privileges whites have because of white supremacy (Lensmire \& Snaza, 2010, p. 413).

This research shows that teacher candidates can learn about empire (Motha, 2014) in a decolonizing way that empowers them to at least marginally take on identities which enable them to talk back to oppressive education from empire, in part by having a social analysis of what creates it, such as having studied the NAFTA trade agreement between Mexico and the U.S. Also, we whole-heartedly agree with Calderon (2014) when she asserts that indigenizing cannot take place without deep understanding of the ways the colonial logic works and surrounds us. Infusing, centering, and adding an indigenizing curriculum in teacher education must linked to anti-colonial methodologies (Calderon, 2014) thereby acknowledging the colonialist challenge 


\section{INDIGENIZING TEACHER EDUCATION}

that indigenizing the curriculum might and will bring. For example, we must be mindful of cultural appropriation, romanticizing indigenous people, and/or a re-avoidance to tackle systemic oppression in teacher education. We point to the work of Arrows (2013) where he provides, from several First Nations perspectives, wisdom on indigenizingmainstream education. With all the reverence that indigenous knowledge deserves, and even though some vehemently oppose the sharing of this wisdom, for Arrows, the time has come. He is reminded of the "Lakota prayer 'Mitakuye Oyasin,' which asserts that 'we are all related' and in the same sinking boat' (p. 76). He further explains that the purpose is not for "corporations or entrepreneurs to utilize indigenous knowledge but to encourage school teachers to follow the guidelines... as best they can. It is time for courage and fearlessness to take hold in all of us for the sake of all future generations" (p. 76).

Finally, we are left with the following to ponder and explore. The predicament or challenge is how the tensions of figured worlds will come into play in the teacher candidates' lives as teachers in actual schools. Will their new decolonizing knowledge and intentions last? To address this question, there is a need for more longitudinal work examining long-term impact. Some indications suggest that results may remain durable. For instance, veteran bilingual/ESOL educator Dr. Alfredo Benavides recognized the white teacher study abroad returnees' greater depths of both understanding and successfully teaching immigrant youth as a program he was associated with decades ago in Iowa and the Yucatán Peninsula in Mexico (Personal communication, 2015). Palmer and Menard-Warwick (2012) found that many pre-service teachers who experienced a similar study abroad program in Mexico indeed directly applied their learning to their teaching with ELL students three years after the study abroad experience. They also acknowledged there is much need for further research in this domain (2012). This would 


\section{INDIGENIZING TEACHER EDUCATION}

shed light on the complexities of maintaining new and critical perspectives in Eurocentric schooling contexts.

Though we have been taught to believe that good intentions are fraught with dangers, indigenous Hawaiian scholar Manulani Aluli Meyer contemplates intentions in a different light. She explains, "the idea that thought creates and intention shapes the observable world may seem farfetched to some, but it is now recognized and discussed in depth by indigenous scholars, quantum physics, mothers, and social scientists and summarized in ground breaking works" (our emphasis, 2008. p. 222). Intentions matter. We know that the ELL teacher candidates in this study, and all teachers in the U.S., will face demands rooted in Eurocentric education as they embark in their teaching careers. And yet, we remain optimistic they will engage the figured worlds as social analysts, empaths, and creators of loving learning spaces to at least some extent, as they have already embodied this new knowing in a way. We know these study abroad returnees have become differently interconnected, in a figured world we hope remains durable, one wherein their intentions may shape realities of interconnectedness of which we may have only begun to dream.

"now let us shift...the path of conocimiento [knowing]...inner work, public acts" (Anzaldúa, 2002, p. 540). 


\section{INDIGENIZING TEACHER EDUCATION}

\section{References}

Anzaldúa, G. E. (2002). now let us shift... the path of conocimiento... inner work, public acts. In G. E. Anzaldúa \& A. Keating (Eds.), This bridge we call home: Radical visions for transformation (pp. 540-578). New York: Routledge.

Anzaldúa, G. E. (2015). Light in the dark/Luz en lo oscuro. A. Keating (Ed).

Author 1, 2014.

Author $1 \& 2,2014$.

Author $1 \& 2,2015$.

Author 2, 2011 already added it

Battiste, M. (2005). Indigenous knowledge: Foundations for First Nations. Retrieved from http://www.winhec.org/docs/pdfs/Journal/Marie\%20Battiste\%20copy.pdf.

Bhattacharya, U. (2011). The "West" in literacy. Berkeley Review of Education, 2(2), 179-198.

Benavides, A. (2015). Personal communication. Oct. 13, 2015.

Bonfil Batalla, Guillermo. (2007). México profundo: Reclaiming a civilization. Austin, TX: University of Texas Press.

Bowen, G. A. (2009). Document analysis as a qualitative research method. Qualitative Research Journal, 9(2), 27-40.

Boylorn, R. M., \& Orbe, M. P. (Eds.). (2013). Critical autoethnography: Intersecting cultural identities in everyday life. Walnut Creek, CA: Left Coast Press.

Brown, A. L. (2005). The "other:” Examining the "other" in education. In S. J. Farenga, B. A. Joyce \& D. Ness (Eds.), Encyclopedia on education and human development (pp. 289292). Armonk, NY: M.E. Sharpe.

Cajete, G. (2000). Native science: Natural laws of interdependence. Santa Fe, NM: 


\section{INDIGENIZING TEACHER EDUCATION}

Clear Light Publishers.

Calderon, D. (2014). Anticolonial methodologies in education: Embodying land and indigeneity in Chicana feminisms. Journal of Latino/Latin American Studies, 6, 81-96.

Curtis, A., Romney, M. (Ed.). (2006). Color, race, and English language teaching: Shades of meaning. Mahwah, NJ: Lawrence Erlbaum.

Darling Hammond, L. (Ed.). (2007). Preparing teachers for a changing world: What teachers should learn and be able to do: Jossey-Bass.

Demas, E. \& Saavedra, C. M. (2004). Reconceptualizing language advocacy: Weaving postmodern mestizaje image of language. In K. Mutua \& B. Swadener's (Eds.) Decolonizing research in cross-cultural contexts: Critical personal narratives, (215-234). NY: SUNY Press.

Emerson, R., Fretz, R., \& Snow, L. (1995). Writing Ethnographic Field Notes. Chicago: University of Chicago Press.

Foley, D. E. (1994). Learning capitalist culture: Deep in the heart of Tejas. Philadelphia: University of Pennsylvania Press.

Foley, D. E. (1997). Deficit thinking models based on culture: The anthropological protest. In R. R. Valencia (Ed.), The evolution of deficit thinking: Educational thought and practice (pp. 113-131). London: The Falmer Press.

Foley, D. E. (2002). Critical ethnography: The reflexive turn. Qualitative Studies in Education, 15(5), 469-490. 


\section{INDIGENIZING TEACHER EDUCATION}

Foley, D. E., \& Valenzuela, A. (2005). Critical ethnography: The politics of collaboration. In N. K. Denzin \& Y. S. Lincoln (Eds.), Handbook of qualitative research (3rd ed., pp. 217234). Thousand Oaks, CA: Sage.

Four Arrows (2013). Teaching truly: A curriculum to indigenize mainstream education. NY: Peter Lang.

González, N., Moll, L. C. , \& Amanti, C.. (2005). Funds of knowledge: Theorizing practices in households, communities, and classrooms. Mahwah, NJ: Lawrence Erlbaum Associates.

Grant, R. A., \& Wong, S. D. (2008). Critical race perspectives, Bourdieu and language education. In J. Albright \& A. Luke (Eds.), Pierre Bourdieu and literacy education (pp. 162-184). New York: Routledge.

Hall, S. (2002). The West and the rest: Discourse and power. In S. Hall \& G. Gieben (Eds.), Formations of modernity (275-331). Cambridge, United Kingdom: Open University/Polity Press.

Holland, D., Lachicotte Jr., W., Skinner, D., \& Cain, C. (2001). Identity and agency in cultural worlds. Cambridge, MA: Harvard University Press.

Holland Herring, D. \& Lave, J. (Eds.). (2001). History in person : Enduring struggles, contentious practice, intimate identities. Santa Fe: School of American Research Press.

Holquist, M. (Ed.). (1981). The dialogic imagination: Four essays by M.M. Bakhtin. Austin: University of Texas Press.

Howard, G. R. 1999. We can't teach what we don't know: White teachers, multiracial schools. Teachers College Press.

Kasun, G. S. \& Saavedra, C. M. (2014). Crossing borders toward young transnational lives. In 


\section{INDIGENIZING TEACHER EDUCATION}

S. Keengwe \& G. Onchwari (Eds.) Cross-cultural considerations in the education of young immigrant learners, (201-217). IGI Global.

Kincheloe, J. L. (2003). Critical ontology: Visions of selfhood and curriculum. Journal of Curriculum Theorizing, 19 (1), p. 47-64.

Kincheloe, J. L. (2008). Knowledge and critical pedagogy. Springer Netherlands.

Kincheloe, J. \& Steniberg, S. (2008). Indigenous knowledges in education:

Complexities, dangers and profound benefits. In N. K. Denzin, Y. S. Lincoln and L.

Tuhiwai Smith (Eds). Handbook of critical and indigenous methodologies (p. 135-156).

Thousand Oaks, CA: Sage Publications.

Kubota, R., \& Lin, A. M.Y. (2006). Race and TESOL Special Issue. TESOL Quarterly, 40(3).

Kumaravadivelu, B. (2003). Beyond methods: Macrostrategies for language teaching. New Haven, CT: Yale University Press.

Lensmire, T. J., \& Snaza, N. (2010). What teacher education can learn from blackface minstrelry. Educational Researcher, 39(5), 413-422.

Liggett, T. (2007). The alchemy of identity: The role of white racial identity in the teaching and pedagogy of new ESOL teachers. In M. Mantero (Ed.), Identity and second language learning: Culture, inquiry, and dialogic activity in educational contexts (pp. 45-70). Greenwich, CT: Information Age Publishing.

Liggett, T. (2009). Unpacking White racial identity in English language teacher education. In R. Kubota \& A. M. Y. Lin (Eds.), Race, culture, and identities in second language education (pp. 27-43). New York: Routledge.

Lincoln, Y. S., \& Guba, E. G. (1985). Naturalistic inquiry. Newbury Park, CA: SAGE Publications, Inc. 


\section{INDIGENIZING TEACHER EDUCATION}

Madison, S. D. (2011). Introduction to critical ethnography: Theory and method Critical ethnography: Methods, ethics, and performance (pp. 1-18). Los Angeles: SAGE.

Marx, S., \& Pray, L. (2011). Living and learning in Mexico: Develping empathy for English language learners through study abroad. Race Ethnicity and Education, 14(4), 507-535.

Meyer. M. A. (2008). Indigenous and authentic: Hawaiian epistemology and the triangulation of meaning. In N. K. Denzin, Y. S. Lincoln and L. Tuhiwai Smith (Eds). Handbook of critical and indigenous methodologies (p. 217-232). Thousand Oaks, CA: Sage Publications.

Motha, S. (2014). Race, empire, and English language teaching. New York: Teachers College Press.

Palmer, D. K., \& Menard-Warwick, J. (2012). Short-term study abroad for Texas preservice teachers: On the road from empathy to critical awareness. Multicultural Perspectives(1), $17-26$.

Peat, D. F. (2002). Blackfoot physics. Boston, MA: Wesiser Books.

Pete, S., Schneider, B., \& O’Reilly, K. (2013). Decolonizing our practice - indigenizing our teaching. First Nations Perspectives, 5(1), 99-115.

Picower, B. (2009). The unexamined Whiteness of teaching: How White teachers maintain and enact dominant racial ideologies. Race Ethnicity and Education, 12(2), 197-215.

Ruiz, D. M. (1997). The four agreements: A Toltec wisdom book. San Rafael, CA: Amber-Allen.

Saavedra, C. M., Chakravarthi, S. \& Lower, J. K. (2009). Weaving transnational feminist methodologies: (Re)examining early childhood linguistic diversity teacher training and research. Journal of Early Childhood Research, 7(3), 324-340.

Saavedra, C. M. (2011). De-academizing early childhood research: Wanderings from a 


\section{INDIGENIZING TEACHER EDUCATION}

Chicana/Latina feminist Researcher. Journal of Latinos and Education, 10(4), 286-298.

DOI: $10.1080 / 15348431.2011 .605678$

Saldaña, J. (2009). The coding manual for qualitative researchers. Los Angeles: SAGE Publications.

Sleeter, C. E. (2001). Preparing teachers for culturally diverse schools research and the overwhelming presence of whiteness. Journal of teacher education, 52(2), 94-106.

Smith, L. T. (2006). Decolonizing methodologies: Research and indigenous peoples. London: Zed Books Ltd.

Trinidad Galván, R. (2011). Chicana transborder vivencias autoherteorías: Reflections from the field. Qualitative Inquiry, 17(6), 552-557.

Valenzuela, A. (1999). Subtractive schooling: U.S. Mexican youth and the politics of caring. Albany, NY: State University of New York Press.

Valencia, R. R. (2010). Dismantling contemporary deficit thinking: Educational thought and practice. New York: Routledge. 